\title{
Algı ve Gerçek Arasında İmam Hatip Okulları: Medyada İmam Hatip Okullarının Başarısının Ele Alınışı Üzerine Bir İnceleme
}

\author{
Hülya Özkan ${ }^{1}$
}

\begin{abstract}
Özet
İmam Hatip okulları geçmişte olduğu gibi bugün de medyanın hakkında sıklıkla haberlere yer verdiği eğitim kurumları olmuştur. Farklı bakış açılarıyla pek çok konuyla gündeme getirilen İmam Hatipler, genellikle basın-yayın organının yayın politikası ve ideolojik tutumunun etkisi altında yeniden tanımlanmakta ve konumlandırılmaktadırlar. Bu çalışmada İmam Hatip okullarının bilimsel başarı durumlarının gazeteler tarafından nasıl aktarıldığı ele alınmaktadır. Bu çerçevede farklı ideolojik yaklaşımlara sahip; Cumhuriyet, Birgün, Aydınlık, Milli Gazete, Sabah ve Star gazetelerinin 2019 yılı içerisinde İmam Hatip okullarının bilimsel başarı durumlarını konu edinen haberleri seçilerek, eleştirel söylem analizi yöntemi ile analiz edilmiştir. Çalışma kapsamındaki haberler incelendiğinde bilimsel başarı haberlerinin sayıca az olması dikkat çekerken, yer verilen haber içeriklerinde Cumhuriyet ve Birgün gazetelerinin yalnızca olumsuz içerikleri konu edindiği, diğer gazetelerde yer verilen pek çok haberde ise İmam Hatiplilik kimliğinin göz ardı edildiği tespit edilmiştir.
\end{abstract}

\section{Anahtar Kelimeler}

İmam Hatip Okulları, Gazeteler, Bilimsel Başarı, Medyada İmam Hatipler

1 Yetkilendirilmiş yazar: İstanbul Medipol Üniversitesi, İletişim Fakültesi, İstanbul, Türkiye, hulyaozkan@medipol.edu.tr, ORCID ID: 0000-0003-4827-664X 


\title{
Imam Hatip Schools Between Perception and Reality: A Study on Perception of Imam Hatip in the Media
}

\begin{abstract}
Imam Hatip schools are institutions where the media frequently report on news today, as in the past. Imam Hatip schools, which have been brought to the agenda with many issues with different perspectives, are generally redefined and positioned under the influence of the publication policy and ideological attitude of the media organ. In this study, how the scientific success of Imam Hatip schools are conveyed by the media is discussed. In this framework, it has different ideological approaches; The news of Cumhuriyet, Birgün, Aydınlık, Milli Gazete, Sabah and Star newspapers, which were about the scientific success of Imam Hatip schools in 2019, were selected and analyzed by critical discourse analysis method. When the news within the scope of the study were examined, it was noticed that the number of scientific achievement news was low, while in the news content, Cumhuriyet and Birgün newspapers only focused on negative content, and in many news published in other newspapers, the identity of Imam Hatip was not highlighted.
\end{abstract}

\section{Keywords}

Imam Hatip Schools, Newspapers, Scientific Success, Imam Hatip in the Media.

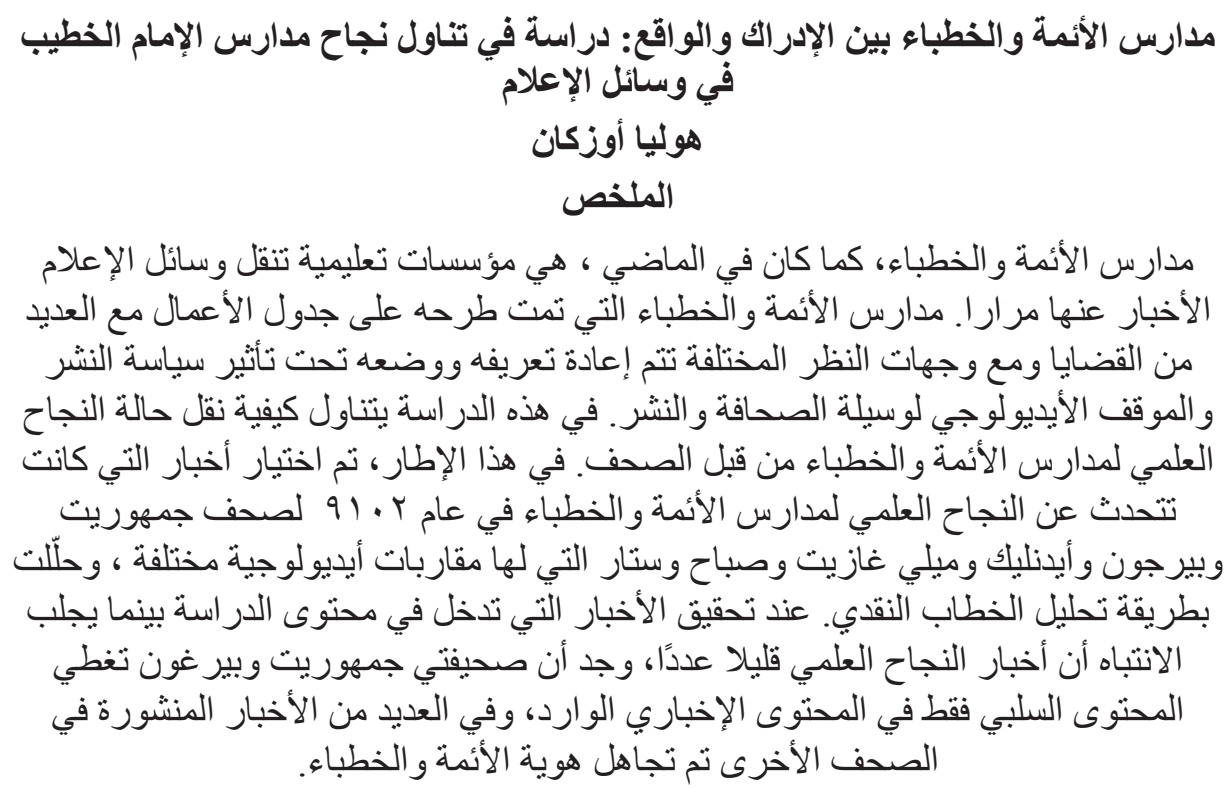




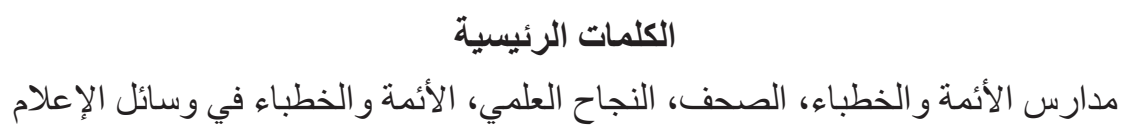

\section{Giriş}

İmam Hatipler birer eğitim kurumu ve temsil ettikleri değerler itibariyle medya organları tarafından sıkça gündeme getirilmektedirler. Gazete, televizyon, sosyal medya gibi pek çok mecrada haklarında çok sayıda haber ve köşe yazılarının yer verildiği İmam Hatipler nitelik, algılanış biçimi ve konumlandırılış itibariyle birbirinden son derece farklı kimliklendirmelere maruz bırakılmaktadırlar.

İmam Hatiplerin gazetelerde yer verilme oran ve biçimleri 2017'den itibaren her y1l ÖNDER İmam Hatipliler Derneği tarafından raporlanmaktadır. Söz konusu raporlarda İmam Hatiplere ilişkin medyada yer verilen haberler taranarak içerik analizine tabi tutulmaktadır. Bu çalışmada söz konusu raporların ortaya koyduğu verilerden de yararlanılarak, İmam Hatiplerin bilimsel başarı durumlarının medyada yer alış biçimi üzerine yoğunlaşılmıştır. Bilimsel başarı kapsamında; merkezi sınavlarda İmam Hatip okullarının sıralaması, ulusal ve uluslararası proje ve yarışmalarda sergilenen performanslar gibi göstergeler ele alınmıştır. Bu çerçevede 2019 yılı içerisinde gazetelerde bilimsel başarı durumlarının yer verilme oranları paylaşılmış ve eleştirel söylem analizine dahil edilecek haber metinleri Cumhuriyet, Birgün, Aydınlık, Milli Gazete, Sabah ve Star gazetelerinde yer verilen haberler arasından belirlenmiştir.

Haber metinlerinin içerik açısından birer söylem olmaları ve inşa edilen söylemlerin ise metnin kendisinden daha etkili olması, haberin içeriğinden çok nasıl aktarıldığ üzerine yoğunlaşmayı gerekli kılmaktadır. Dolayısıyla haber metinlerinin eleştirel söylem analizi kapsamında makro ve mikro yapılar bağlamında ele alınıp incelenmesi söz konusu metnin gelişiminden önce kendisini oluşturan ard dünyasını anlaşılır kılmaktadır. Gazetenin, muhabirin inşa ettiği söylem, habere yapılan olumlu ve olumsuz editöryal katkıyı da ortaya koymaktadır.

İmam Hatip okullarının bilimsel başarının medyada yer verilme biçiminin konu edildiği bu çalışmada belirlenen gazetelerde yer alan haberlerin ardındaki ideolojik belirlenimlerin tespiti amaçlanmış ve van Dijk'ın eleştirel söylem analiz modeli temel alınarak haberlerin nasıl inşa edildiği üzerinde durulmuştur. Haber metinleri incelendiğinde İmam Hatip okullarına yönelik bakış açısının, söz konusu okulların bilimsel başarılarına yönelik yaklaşımı da şekillendirdiği ortaya çıkmaktadır. Dünya görüşü olarak dindar ya da muhafazakâr şeklinde ifade edilen gazeteler, İmam Hatip okullarının bilimsel başarı durumlarını olumlu haber içerikleri ile sunarken, söz konusu okulları iktidar partisiyle adeta özdeşleştiren ve hemen her haberinde İmam Hatiplere ilişkin olumsuz bir bakış açısı sunan gazeteler ise bilimsel başarı haberlerine yer vermeden İmam Hatipler için "başarısız" okul tablosu çizmektedirler. 


\section{Medya ve Algı: Gündem Belirleme Kuramı}

Sözlük anlamı itibariyle Türkçede gün kökünden türeyen gündem sözcüğü (Ozankaya 1980), zamanın belirli bir noktasında öncelik ve önemine göre siralanan olay ve gelişmeler şeklinde tanımlanabilmektedir. Gündemler, dinamik bir etkileşimin sonucu olmakla birlikte olayların zamanla önem kazanmaları ve önem kaybetmeleri ile akışkan bir görüntü sunmaktadır (Terkan 2005).

Medyada yer verilen sosyal, siyasal, ekonomik ya da kültürel temelli pek çok mesele Gündem Belirleme Kuramı bağlamında ele alınabilir. Zira basın organları pek çok olay/gelişmeyi kamuoyunun gündemindeki diğer konular çerçevesinde ele alarak, söz konusu sosyal kurumların birbirleriyle ilişki ve etkileşimini ortaya koymaktadırlar. Gündem Belirleme Kuramı, medyanın yer verdiği içerikler ile kamuoyunun üzerine yoğunlaştığ1 ve gündemi haline getirdiği konular üzerinde belirleyici olduğu görüşüne dayanmaktadir.

Gündem Belirleme Kuramına ilişkin ilk çalışmalar 1960'lı yıllarda yapılmaya başlanmıştır. Söz konusu çalışmaların başında Shaw ve McCombs'un 1968'deki $\mathrm{ABD}$ başkanlık seçimleri sürecinde gündem belirlemenin etkilerini ölçmeye yönelik araştırmaları gelmektedir. Gündem belirlemenin halkın üzerinde bıraktığı tesiri belirlemeyi hedefleyen söz konusu çalışmalar neticesinde medya tarafından halka aktarılan birçok içeriğin izleyiciler üzerinde bilişsel etkiler yarattığı gözlemlenmiştir (Yaylagül 2006, 82). Dolayısıyla medya her ne kadar çoğu zaman hedef kitlenin ne düşüneceklerini belirlemede etkin güç olamasa da izleyicilerin ne hakkında düşünmeleri gerektiği noktasında son derece belirleyici bir güç olduğunu söylemek mümkündür (Güneş, 2014).

Medyanın servis ettiği içerikler halkın ilgisini çeker ve medyada yer verilmeyen, gündemleştirilmeyen konular ise dikkat çekmez. Bir olay ya da durumun izleyici tarafından öneminin derecesi, medya organının söz konusu olay ya da duruma ne sıklıkta, haberin ne uzunlukta ve genişlikte yer verildiğine göre şekillenmektedir.

Said'in de belirttiği üzere, medya tarafından üretilen içerikler/şeyler bir anda ya da kendiliğinden ortaya çıkan "serbest" şeyler değillerdir. Söz konusu içerikler/haberler kendiliğinden oluşmazlar, resimler ve imgeler kendiliğinden bir yerden firlayıp gözlerimize ve zihnimize girmez; hakikat doğrudan doğruya elimizin altında değildir, dizginsiz çeşitlilik de bizim tasarrufumuzda değildir (Said 2006, 122).

$\mathrm{Bu}$ bakış açısından hareketle, medya üzerinden aktarılan haberler, söylemler kamuoyu oluşturma ve yönlendirme hususunda başvurulan öncelikli araçlardır. "Haberler" ve "öteki şeyler"den oluşan medya içeriğinde haberlerin aktarılma biçimleri, haberlerin seçimi ve inşa edilen söylemleri çok daha geniş ve yanıltıcı bir etki alanı oluşturabilmektedir (Girgin, 2002). Medya bir yandan egemen ideolojinin söylemini iletirken, diğer yandan ise kendi söylemini egemen ideolojinin söylemi şeklinde de 
sunabilmektedir. Haber anlam yükü olan bir "hikayeden" hareketle oluşturulan ve aynı zamanda içerdiği sözcüklerin ötesinde göndermede bulunulan "söylem”" şeklinde toplumsal ilişkiler bütünü içerisinde anlaş1labilecektir (Ergül 2005). Söylemsel oluşumun taşıyacağı tutarlılık hegemonik bir tutarlılık teşkil ederken, aynı zamanda hegemonik mantıklar da söylemsel oluşumlar düzeyinde etki yaratabilmektedirler (Laclau 2009, 311-340).

Çalışma kapsamında gazetelerin İmam Hatip okullarının bilimsel başarısına dair yer verdikleri haber oranları söz konusu okulları gündeme getirme hususundaki yaklaşımlarını ortaya çıkarmaktadır. İncelenen haberlerde inşa edilen söylemlerde ise basın organının ideolojik yaklaşımının etkisi açıkça görülebilmektedir.

\section{Medyada İmam Hatiplerin Bilimsel Başarı Durumu}

İmam Hatip okullarının bilimsel başarı durumlarının medyada yer verilme oran ve biçimine bakıldığında, merkezi sınavlarda elde edilen başarıların, yarışma ve diğer sınavlarda kazanılan başarıların belli gazeteler tarafından neredeyse hiçbir şekilde yer verilmediği, bazı verilerin göz ardı edilerek başarının adeta manipüle edildiği anlaşılmaktadır.

İmam Hatiplerin bilimsel başarılarının sıklıkla yer verildiği medya organlarında ise, çeşitli alanlarda elde edilen başarılı sonuçların yerine İmam Hatiplerin yalnızca hafızlık eğitimi verilen eğitim kurumları şeklinde aktarıldığı görülmektedir.

İmam Hatiplerin medyada yer verilmelerine ilişkin yapılan araştırmalarda İmam Hatiplere ilişkin en fazla haberin Yeni Akit, Cumhuriyet, Birgün ve Star gazetelerinde yer aldığı tespit edilmiştir. Gazetelerde yer verilen haberlerde İmam Hatiplere yönelik olumlu ve olumsuz haber dağılımı aşağıdaki gibidir: ${ }^{2}$

2 Gazetelerde Imam Hatiplere Bakış 2019, (Editör: Emine Dolmac1), İstanbul, 2019, s.18. 


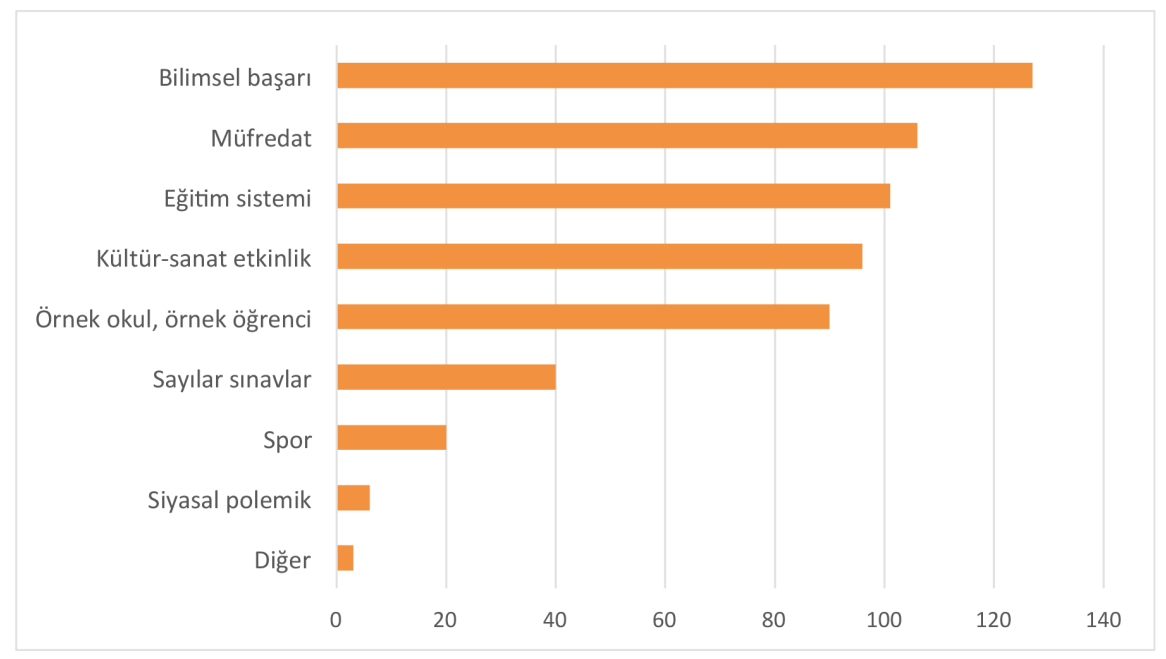

Sekil 1

Haber Kategorisine Göre- Olumlu Haberler

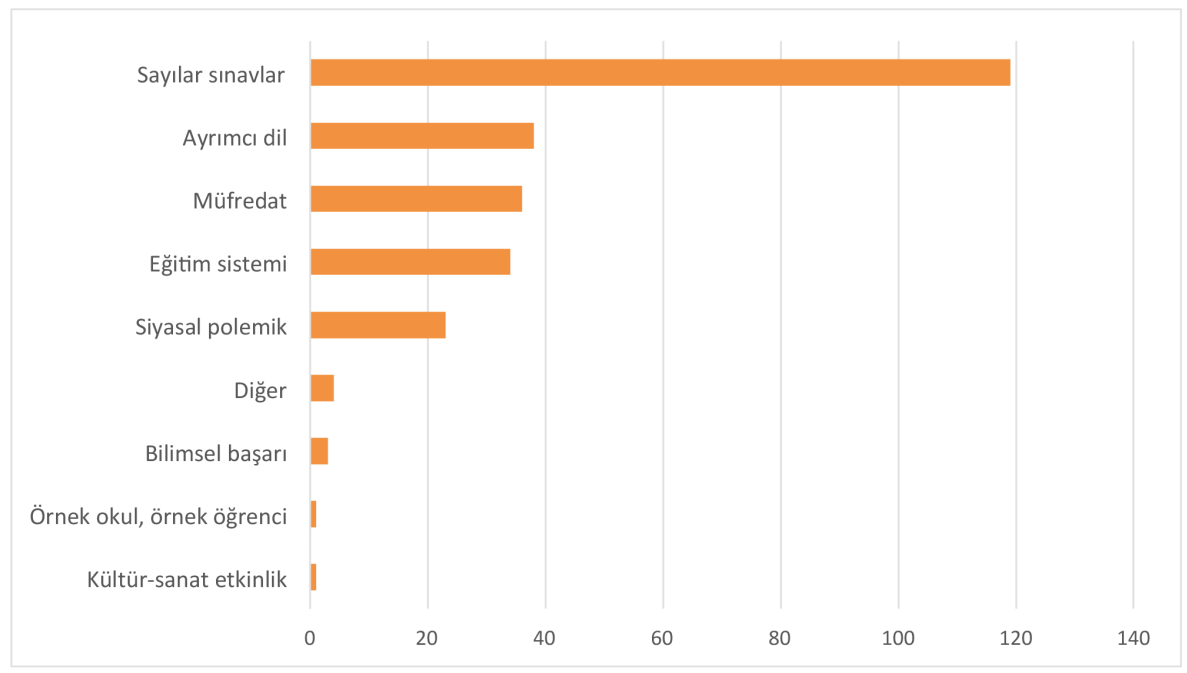

Şekil 2

Haber Kategorisine Göre- Olumsuz Haberler 


\section{Araştırmanın Yöntemi: Eleştirel Söylem Çözümlemesi}

Toplumsal denetimin sağlanmasının etkili araçlarından biri olarak söyleme işaret eden Teun A. van Dijk, söz konusu denetimin sağlanmasının şartının ise söylemin denetlenmesi ve üretilmesi olduğuna dikkat çekmiştir. Medyada İmam Hatip okullarına yönelik bakış açısının belirlenmeye çalışıldığı bu araştırmada, ele alınan haberlerin söylem yapılarının ve süreçlerinin ideolojik bir yeniden üretim süreci olduklarının ortaya çıkarılması açısından eleştirirel söylem analizi uygun bir model olarak belirginlik kazanmaktadır. Bu çerçevede çalışma kapsamında gazetelerde yer verilen haberler birer söylemsel materyal olarak ele alınmış (İnal 1996, 29) ve van Dijk'ın eleştirel söylem analizi modeline göre değerlendirilmiştir. Böylelikle incelenen haberlerin kaynakları, temaları, sözcük seçimleri, ardalan ve bağlam ilişkileri söylemsel olarak çözümlenmiştir.

Teun A. van Dijk, eleştirel söylem analizi modelinde, makro ve mikro yapı şeklinde iki temel başlık altında haber metni ele alınmaktadır. Makro yapı çözümlemesinde haber metninde işlenen tema ve haber üretiminde faydalanılan unsurlar incelenmektedir. Modele göre haber üretimi profesyonel olarak sürekli aralıklarla yapılmakta ve söz konusu üretim şeması ile organizasyonu sağlanmaktadır (Dijk 1988, 15). Dolayısıyla haberin başlı̆̆ 1 , haberin spotu, haberin girişi, ana olay/tema, kaynaklar, taraflar, olaya dair fotoğraflar vb. unsurlar makro yapı çözümlemesi kapsamında değerlendirilmektedir (Özer 2001, 83).

Eleştirel söylem çözümlemesinin yapıldığı bir diğer bölüm ise mikro yapıdır. Mikro yapı bağlamında ise sözcüklerin seçimi, bölgesel uyum, haberin retoriği ve sentaktik çözümlemelere yer verilmektedir. Haber metninde yer verilen cümlelerin basit ya karmaşı, etken ya da edilgen mi olduklarına bakılmaktadır. Haberde ideolojik yaklaşımın tespiti açısından ise özellikle sözcük seçimlerine dikkat çekilmektedir. Bölgesel uyum çözümlemesinde ise haberde yer verilen cümleler arasındaki işlevsel, referansal ve nedensel ilişkinin tespiti yapılmaktadır (Doruk 2013, 106-132).

\section{Haber Metinlerinin Çözümlemesi}

Çalışma kapsamında 2019 yılı içerisinde ulusal medyada İmam Hatip Liselerinin bilimsel başarılarına ilişkin yer verilen haberler incelenmiş ve gazetelere yansıyan 130 haber tespit edilmiştir. Söz konusu haberlerden rastgele seçilen örnek haber metinleri ise eleştirel söylem analizi yöntemiyle tahlil edilerek gazetelerin İmam Hatip Liselerinin bilimsel başarılarına yönelik yaklaşımları tespit edilmiştir.

Milli Gazete, Sabah, Star, Cumhuriyet, Birgün ve Aydınlık gazetelerinde İmam Hatiplerin bilimsel başarılarına ilişkin yer verilen haberlerden birer örnek seçilerek, makro ve mikro düzeyde incelenmiştir. Bu bağlamda özellikle Cumhuriyet ve Birgün gazetelerinde İmam Hatiplere yönelik olumsuz yaklaşım dikkat çekerken, Milli Gazete'de ise "İmam Hatip" kimliğinin ön plana çıkarıldığı görülmektedir. 


\section{Makro Yapı: Tematik ve Şematik Çözümleme}

Haberde makro bağlamda ele alınan öğeleri başlıklar, haber girişleri, spotlar, spot yoksa haberin ilk paragrafi, ana olay, bağlam ve ardalan bilgisi, haberin kaynağı, habere konu olan olayın tarafları, fotoğraflar oluşturmaktadır.

Tematik yapı incelemesi yapılırken, haberin başlığı, spotu, girişi, spota yer verilmeyen haberlerde haberin ilk paragrafı ele alınmaktadır. Çalışma kapsamındaki haberin başlıkları numaralandırılmış ve her bir haberin spotu tematik yapı bağlamında analiz edilmiştir.

Şematik yapı incelemesinde ise durum ve yorum şeklinde iki başlık altında ana olayın aktarımı, bağlam ve ardalan bilgisi ile sonuçlar çerçevesinde değerlendirme yapılmıştır. Haber metinlerinde ana olayın bilgisinin haber girişlerinde özetlenerek yer verildiği görülmektedir.

\section{Başlıklar}

Çalışma kapsamında incelenen haber başlıklarında zaman, yer, olayın tarafları gibi bilgilere yer verilmediği görülmektedir. Haber başlıklarında enformasyon eksiltimine gidildiği ve belli şemsiye kavramlar ile genelleştirmelerin yapılarak haberlerin okurlara aktarıldığı saptanmaktadır.

2019 yılına ait örneklem olarak seçilen haber başlıkları aşağıdaki gibidir;

1. Geriden geliyorlar (Cumhuriyet, 5 Aralık 2019)

2. Hesap oyunuyla da başarısız oldular (Birgün, 5 Aralık 2019)

3. Robotik Yarışması'nda 'imkansızı' başardılar (Aydınlık, 17 Ağustos 2019)

4. LGS'ye imam hatip damgası (Milli Gazete, 29 Haziran 2019)

5. Erkeklerde olan beyin bizde de var (Sabah, 26 Ocak 2019)

6. Liseliler Teknofestte başarı hikayesi yazdı (Star, 28 Eylül 2019)

2019 yılında İmam Hatiplerin bilimsel başarılarının yer verildiği haber metinlerinde kullanılan başlıklarda Aydınlık, Milli Gazete ve Sabah gazetelerinde haberlerin ana temalarını yansıtır nitelikte iken, Birgün, Cumhuriyet ve Sabah gazetelerinde yer alan haber başlıklarının ise haberlerin ana temasını yansıtmadığı anlaşılmaktadır. Söz konusu haber başlıklarında enformasyon eksiltimine gidildiği görülmektedir.

3, 4 ve 6 no.lu haberlerde bilimsel başarının sağlandığı sınav ya da yarışmaya ilişkin bilgi paylaşımına yer verilirken, 1,2 ve 5 no.lu haber başlıklarında ise yer verilen bilimsel başarı/başarısızlık alanına dair herhangi bir bilgi paylaşımında bulunulmamıştır. Cumhuriyet gazetesinde "geliyorlar" sözcüğü ile bir kurgu söz konusu iken taraflara dair herhangi bir açıklayıcı ifadenin kullanılmadığı saptanmıştır. Benzer şekilde Birgün gazetesinin haber başlığında "başarısız oldular" şeklindeki ifade kullanılırken taraflara 
yönelik bilgi paylaşımı söz konusu olmamıştır. Sabah gazetesinin haber başlığında da olaya ve taraflara yönelik bilgi eksikliği dikkat çekmektedir.

Aydınlık gazetesini haber başlığında "başardılar" sözcüğü ile bilimsel başarı doğrudan başlıkta yer verilse de taraflara ilişkin herhangi bir bilgi yer almamıştır. Milli Gazete ise kullandığı "LGS'ye imam hatip damgası" şeklindeki başlık ile İmam Hatip vurgusu yaparak bilimsel başarının sahiplerini özellikle ön plana çıkarılmıştır.

\section{Haber Spotları}

Haberde başlıklardan sonra gelen spotlar, okurlara ana olayın kısaca aktarıldı̆̆ ve haber metnini özetleyen bölümlerdir. Çalışma kapsamında incelenen gazeteler; Cumhuriyet, Birgün, Aydınlık, Milli Gazete, Sabah ve Star'da yer verilen haberlerin tamamında haber spotlarının yer aldığı tespit edilmiştir.

"AKP'nin "dindar nesil" umudu imam hatip liseleri PISA 2018'de çakıldı. Imam hatipler uluslararası değerlendirmede de akademik ĕgitim veren liselerin gerisinde kaldı." (Cumhuriyet)

“MEB'in başarı olarak sunduğu PISA'da 2015 'e göre örneklem değişti. Örneklemde fen ve Anadolu lisesi gibi başarılı okulların oranı artarken başarısız okulların oranı düştü..” (Birgün)

“Türkiye Dünya Robotik Yarışması'nda ilk defa dereceye girdi. Imkansız Görev kategorisinde yarışan liseli takım, Kore Savaşı'nda şehit olan Türk askerlerin mezarlarını da ziyaret ederek, başarılarını şehitlere ithaf ettiler." (Aydinlık)

“Liselere Geçiş Sistemi kapsamında 1 Haziran'da yapılan merkezi sınavda tüm soruları doğru yanttlayarak tam puan alan 565 ögrenciden 24'ünün Imam Hatip ortaokullarında eğitim gören öğrenciler olduğu bildirildi." (Milli Gazete)

"Tenzile Erdoğan Kiz Anadolu Imam Hatip Lisesi'nde okuyan 17 ögrenci dünyanın en prestijli robot yarışmasına katılmaya hak kazandı. Türkiye'den giden sayılı takımlar arasına giren kız takımı, geliştirdikleri robot ile 24 Mart'ta New York'ta ülkemizi temsil edecek.” (Sabah)

"Dünyanın en büyük ikinci hava etkinliği olan ve bu yul ikinci kez gerçekleştirilen Teknofest Istanbul Havacılık, Uzay ve Teknoloji Festivali, Türk gençlerinin içindeki bilim aşkını ve cevherini açığa çıkardı. Teknofest Roket Yarısmasında M. Emin Saraç Anadolu Imam Hatip Lisesi ögrencileri birinci olurken Tenzile Erdoğan Kiz Anadolu Imam Hatip Lisesi Techtolia ekibi de Teknofest Uçan Araba Tasarımı kategorisinde Türkiye üçüncülüğ̈̈nü kazandı." (Star) 
Haber spotlarında 5N 1K'nın; ne, ne zaman, nerede, nasll, neden ve kim sorularının cevaplarının olup olmadığı değerlendirmesi yapıldığında, Cumhuriyet gazetesinin haberinde yer verilen spotta olayla/gelişmeyle ilgili olarak okuyucu ile bazı bilgilerin paylaşıldığı görülmektedir. Haberin başlığında yer verilen "Geriden geliyorlar" ifadesi ile kurgulanan grubun kim olduğu bilgisi haberin spotunda “AKP'nin dindar nesil umudu imam hatip liseleri" şeklinde ifade edilmiştir. Haberin spotunda ayrıca bilimsel başarısızlığın gerekçesi olarak PISA 2018 sonuçlarına işaret edilirken, İmam Hatip liseleri için kullanılan “AKP'nin dindar nesil umudu” şeklindeki ifadesi ile okuyucunun haber metninin tamamını okumadan habere konu olan gelişmeye dair yönlendirildiği görülmektedir.

Birgün gazetesinin başlık ve spotu birlikte ele alındığında başlıkta işaret edilen "başarısızlık" nedeni spotta yeteri düzeyde açıklanamamıştır. Zira haber başlığında dikkat çekilen "başarısızlık" durumunun faili haber metninde İmam Hatip Liselerine mal edilirken, spotta paylaşılan bilgiler arasında İmam Hatiplerin PISA sonuçları üzerindeki etkisine dair herhangi bir enformasyona rastlanmamaktadır. Benzer durum Aydınlık gazetesinin yer verdiği bilimsel başarı haberinin spotunda karşımıza çıkmaktadır. Bilimsel başarı sahibi İmam Hatip lisesi öğrencileri spotta "liseli takım" şeklinde ifade edilmiştir.

Milli Gazete'nin yer verdiği haberin spot bölümünde ana olaya dair bilgilere yer verilirken, sayısal veriler ile bilimsel başarıya ilişkin ayrıntı paylaşılmıştır. Aynı şekilde Sabah ve Star gazetelerinde yer verilen haberlerde de ana olaya ilişkin gerekli yer, zaman ve taraflara ilişkin bilgiler eksiksiz olarak okuyucuya aktarılmıştır.

\section{Fotoğraflar}

Makro yapı incelemesi kapsamında değerlendirilen fotoğraflar incelendiğinde, söz konusu haber anlatılarında oluşturulmak istenen algıyı destekler özellikler taşıdıkları anlaşılmaktadır. Haberlerde yer verilen fotoğrafların dağılımına bakıldığında; Cumhuriyet ve Birgün gazetelerinde 1'er, Aydınlık gazetesinde 2, Milli Gazete'de 4, Sabah ve Star gazetelerinde ise 3'er görselin haber sunumunda kullanıldığı saptanmıştır.

Star gazetesi haberin ana temasını oluşturan "başarı ödülü” ile uyumluluk gösteren ödül töreni görsellerine yer verirken, Sabah gazetesi de başlığında da işaret ettiği kız öğrencilerin iki görselini haberinde kullanmıştır. Milli Gazete ise, "LGS'ye İmam Hatip Damgası”nı vurduğunu belirttiği öğrencilerin görsellerine yer vermiştir.

Birgün ve Cumhuriyet gazetelerinde ise konu edindikleri "başarısızlık" durumuna ilişkin yer verdikleri haberlerinde yüzü görünmeyen, arkası dönük öğrencilerin görsellerini kullanmayı tercih etmişlerdir. $\mathrm{Bu}$ çerçevede gazetelerde yer verilen fotoğrafların, haberlerin başlıklarında işaret edilen "başarı" ya da "başarısızlık" durumlarının haber anlatısında sunulmaya çalışılan tema ile uyumluluk ve bütünlük gösterdiğini söylemek mümkündür. 


\section{Ana Olayın Sunumu ve Sonuçlar}

Çalışma kapsamında incelenen haberlerin spotlarında PISA sonuçlarının, İmam Hatip Lisesi öğrencilerinin yarışmalardaki ve merkezi sınavlardaki başarılarının ana olaylar olarak sunulduğu tespit edilmiştir. Sınavlarda ve yarışmalarda elde edilen başarılar yani olayların sonuçları gazeteler tarafından haber değerliliği ölçütleri bağlamında önemli görülerek aktarılmıştır.

Bu çerçevede yan anlam düzeyindeki çözümleme neticesinde söz konusu haberlerde İmam Hatip liselerine yönelik belli yaklaşımlar ön plana çıkmaktadır. Başarı haberlerinin sıklıkla yer verildiği gazetelerde İmam Hatip kimliği genellikle ön plana çıkarılırken, başarısızlık durumunun yer verildiği gazetelerde ise genellemelere gidilerek söz konusu liselere ilişkin olumsuz bir tablo çizilmektedir.

\section{Ardalan ve Bağlam Bilgisi}

İncelenen haberlerde makro yapı çerçevesinde şematik yapı incelemesinin önemli bir öğesi olan ardalan ve bağlam bilgisi bağlamında bazı haberlerde yeterince bilgi verilmediği görülmektedir. Çalışma kapsamında analiz edilen haberlerden özellikle İmam Hatip liselerine atfedilen başarısızlık durumuna ilişkin ardalan ve bağlam bilgisinin yeterince aktarılmadığı dikkat çekmektedir.

Cumhuriyet gazetesinde, "İmam hatipler uluslararası değerlendirmede de akademik eğitim veren liselerin gerisinde kaldı.” şeklindeki ifadeler kullanılırken, uluslararası değerlendirme dışında başka diğer değerlendirmelerde de başarısız sonuçların elde edildiği ileri sürülürken, iddia edilen başarısızlık durumuna dair herhangi bir bilgiye haber metninde yer verilmediği görülmektedir. Söz konusu haberde olay/durum, gazete okurunun kendi bakış açısıyla konuyu değerlendirmesine firsat tanımayan bir yaklaşımla haberin sunulduğu belirlenmiştir.

Birgün gazetesinde yer alan PISA sonuçları değerlendirilirken ardalan bilgisine yeteri düzeyde yer verilmiştir. Milli Gazete'de başarıya ilişkin ardalan bilgisi bağlamında “İstanbul Kartal Hürriyet İmam Hatip Ortaokulu öğrencisi Samet Furkan Memiş, sınava hazırlanırken hocaların kendisine çok destek olduğunu belirterek..." şeklindeki ifadelere yer verilirken, İmam Hatip Liselerinin geçmişteki başarı durumlarına yönelik herhangi bir bilgi paylaşımı yapılmamıştır. Star'da yer verilen haberde ise ayrıntılı bir şekilde “TEKNOFEST'te başarı hikâyesi”"nin ardalan ve bağlam bilgisinin yer aldığı görülmektedir.

\section{Haber Kaynakları ve Olay Taraflarının Değerlendirmeleri}

Çalışma kapsamında incelenen haberlerde İmam Hatiplerin bilimsel başarılarını ön plana çıkaran haber içeriklerinde birincil kaynağa başvurulduğu yani muhabirin kendi gözlemlerinin aktarıldığı görülmektedir. Cumhuriyet ve Birgün gibi bilimsel başarı konusunda genellikle İmam Hatip liselerine "başarısızlık" atfeden basın organlarının haberlerinde ise doküman, belge gibi ikinci el kaynaklara da başvurulmuştur. 
Birgün gazetesinde yer verilen haberde "Örneklemde Fen ve Anadolu lisesi gibi başarılı okulların oranı artarken başarısız okulların oranı düştü.” şeklindeki açıklama ile İmam Hatip liselerine yönelik "başarısız" nitelemesi yapılırken, haberde kaynak olarak PISA'nın geçmişteki raporlarından yararlanılmıştır. Ayrıca uzman görüşüne de başvurularak, "Üniversite Araştırma Laboratuvarı kurucularından Prof. Dr. Engin Karadağ 2018'deki PISA'da başarılı okullardan olması gerekenden daha fazla örneklem alındığını ifade etti." ifadeleri ile atfedilen başarısızlık durumu pekiştirilmeye çalışılmıştır. Cumhuriyet gazetesinde yer verilen haberde ise, "Fen liselerinin imam hatiplere her alanda yaklaşı 150 puan fark atması dikkat çekti." şeklindeki ifadeler ile haber metninde sözü edilen liseler arasında bir karşılaştırma yapılarak, İmam Hatiplilere atfedilen "başarısızlık” durumu bir kez daha gündeme getirilmiştir. Yalnızca PISA 2018 raporundan elde edilen veriler kaynak gösterilerek oluşturulan haber metninde İmam Hatipler ve diğer liseler arasında sıklıkla karşılaştırmalara gidilmesi dikkat çekicidir.

Milli Gazete'de yer verilen haberde kaynak kullanımına bakıldığında, “Önder İmam Hatipliler Derneği Genel Başkanı Kamber Çal...”; “İstanbul Kartal Hürriyet İmam Hatip Ortaokulu öğrencisi Samet Furkan Memiş...”; "İstanbul Esenyurt Güzelyurt Kız İmam Hatip Ortaokulu öğrencisi Hilal K1lıç...” şeklinde birincil haber kaynaklarına başvurulduğu görülmektedir. Benzer şekilde Sabah ve Star gazetelerinde de birinci kaynakların açıklama ve değerlendirmelerine geniş yer verilmiştir.

Olay/duruma ilişkin taraflar konusunda ise Cumhuriyet ve Birgün gazetelerinde İmam Hatip Liseleri ve diğer liseler şeklinde bir konumlandırma yapılırken, diğer gazetelerde bu şekilde bir konumlandırma ve karşılaştırmadan söz etmek mümkün değildir.

\section{Mikro Yapı}

Mikroyapıçözümlemesiyapılırkenhabermetinlerindetercihedilen sözcükseçimlerine dikkat çekilerek, bölgesel uyum ve sentaktik inceleme üzerinde durulmaktadır. Haber metninde yer verilen cümlelerin yapılarının basit ya da karmaşıklığı, tarafların etken ya da edilgen biçimde sunulması, cümleler arası işlevsel ve nedensel ilişkiler gibi unsurlara bakılmaktadır. $\mathrm{Bu}$ çerçevede çalışma kapsamında incelenen haberlerin sentaktik çözümlemesi, bölgesel uyum ve sözcük seçimleri aşağıdaki gibi ele alınmıştır;

\subsubsection{Sentaktik Çözümleme}

Haber metninin mikro yapı çerçevesinde sentaktik çözümlemesi yapılırken haberde yer alan cümlelerde öznenin konumlandırılışı, cümlenin yapısı ve nasıl kurulduğu incelenmektedir. Bu çerçevede Cumhuriyet ve Birgün gazetelerinde yer verilen,

"Fen alanında da 584.9 puan ortalaması ile fen lisesi öğrencileri ilk sırada yer alırken, sosyal bilimler lisesi öğrencileri 512.7, Anadolu lisesi öğrencileri de 498.6 puan ortalaması yakaladı. İmam hatip liseleri ise 446 puanda kaldı.” (Cumhuriyet) 
"Anadolu lisesi, fen lisesi ve sosyal bilimler lisesinde eğitim alan öğrenciler bu alanda OECD ortalamasının üzerinde performans gösterdi. İmam hatipler, meslek lisesi ve çok programlı, liseler ise ortalamayı düşürdü." (Cumhuriyet)

"Fen liselerinin imam hatiplere her alanda yaklaşık 150 puan fark atması dikkat çekti." (Cumhuriyet)

"Örneklemde en dikkat çekici unsur fen lisesi, Anadolu lisesi gibi başarılı liselerin oranlarının artması, meslek lisesi ve imam hatip lisesi gibi başarısız olan liselerin ise oranlarının düşmesi oldu.” (Birgün)

şeklindeki cümlelerde İmam Hatiplilerin bilimsel başarı durumları edilgen bir yapıyla yer verilirken, diğer liselerin başarı durumlarının aktarıldığı cümleler genellikle etken bir yapıyla sunulmuştur. Diğer gazetelerde yer verilen haberler incelendiğinde İmam Hatiplilerin bilimsel başarılarının aktarıldığı cümle yapılarının etken olduğu tespit edilmiştir.

\section{Bölgesel Uyum}

Bölgesel uyum incelemesinde haber metninde yer verilen cümlelerin işlevsel, nedensel ve referansal ilişkileri ele alınarak cümleler arasındaki nedensel bağlar, genel ifadelere dair ardıl cümlelerde açıklama getirilip getirilmediği gibi hususlar üzerinde durulmaktadır. Çalışma kapsamında incelenen haber metinlerinde Cumhuriyet gazetesinin haberinde başarısızlık durumuna ilişkin nedensel ve işlevsel ilişkiye dair bir anlatımın kurulmadığı dikkat çekerken, bilimsel başarının ön plana çıkarıldığı haber metinlerinde ise başarıya zemin hazırlayan nedenlerin neler olduğu üzerine yoğunlaşılarak nedensel bir ilişkinin kurulduğu görülmektedir.

"Fen liseleri ve sosyal bilimler liseleri, Türkiye ve OECD ortalamasının üzerinde yer ald1. Anadolu liselerinde eğitim alan öğrenciler, her üç alanda da imam hatip liseleri, mesleki ve teknik liselerinde eğitim alan öğrencilerden daha yüksek ortalamaları ile dikkat çekti." (Cumhuriyet)

Birgün gazetesinde yer verilen haberde ise başarısızlık duruma ilişkin nedensellik aşağıdaki gibi örneklem değişikliği ile açıklanarak verilmiştir;

“2015 yılında okullardan alınan örneklemin değişmesi nedeniyle alınan puanlardaki yükseliş gerçeği yansıtmadı. Bir önceki PISA'ya göre genelde başarılı okullar seçilerek örneklem oluşturuldu. $\mathrm{Bu}$ da puanların yüksek çıkmasını sağladı. Buna rağmen sınavların kendi içindeki ortalamasını değerlendiren Z puanına göre sonuçlar 2009 yılının da gerisine düştü.” (Birgün)

Star gazetesinde yer verilen haberde ise, başlıkta belirtilen "başarı hikayesi” nedensel ve işlevsel dayalı bir anlatımla aktarılmıştır; 
"M. Emin Saraç Anadolu İmam Hatip Lisesi öğrencilerinin kurduğu Çargah Roket Takımı bu seneki Teknofest Roket Yarışmasına başvuran 571 takım arasından sıyrılarak Alçak İrtifa kategorisinde birinci oldu.” (Star)

"Takım üyelerimiz geçen yıl düzenlenen TEKNOFEST yarışmasında o senenin roket yarışmasında atılmış ve sergilenen roketleri görmüş. Onlardan etkilenerek "Biz neden yapmayalım?" diyerek bu takımı oluşturdu. Uzay ve havacılık konusunda merakımız olmasına rağmen çok detaylı bilgiye sahip değildik. Bu yüzden ilk iş olarak takımımızı kurduktan sonra detaylı bir araştırma sürecine başladık." (Star)

"İlk hedefimiz yarışmada finale kalmaktı. Bu yüzden çok çalıştık. Sonuçta finale kaldık. Sunum yapmaya başladığımızda güzel tepkiler aldık ve bu sayede kendimizi daha iyi hissettik. Daha sonra jürinin önünde yapmış olduğumuz sunumu da başarıyla tamamladık. Projeye hazırlanırken solidworks, adobe premiere, adobe photoshop, tinkercad programlarını öğrendik. Bu proje sayesinde kendimizi geliştirdik, arkadaşlıklar edindik, mühendislerle ve işin uzmanlarıyla tanışıp sohbet ettik.” (Star)

Yer verilen cümlelerden de görüldüğü üzere "başarı hikayesi”nin hangi aşamalardan geçilerek elde edildiği nedensel bir ilişki kurularak açıklanmıştır.

Milli Gazete'de yer verilen haberde ise "LGS'ye İmam Hatip damgası",

“... tüm soruları doğru yanıtlayarak tam puan alan 565 öğrenciden 24'ünün İmam Hatip ortaokullarında eğitim gören öğrenciler oldu..” şeklinde nedensel bir ilişki ile açıklanmıştır.

\section{Sözcük Seçimleri}

Haber metinlerinde tarafların tanımlanması ve olayın aktarılması aşamasında seçilen sözcükler söz konusu haberin muhabirinin ve yayın organının ideolojik yaklaşımını yansıtan en önemli göstergelerdir. Zira haberin okurlara aktarılmasında habere konu olan tarafların konumlandırılma biçimi, olaya/duruma ilişkin olumlu/olumsuz bakış açısı okuyucuya taraflar ve olaya ilişkin belli bir çerçeve sunmaktadır.

Mikro yapı bağlamında ele alınan sözcük seçimi, haber söyleminde anlamın oluşması aşamasında kritik bir önem taşımaktadır. Bu bağlamda çalışma kapsamındaki haber metinleri incelendiğinde muhabirin ve gazetenin ideolojik yaklaşımının sözcük seçimlerine doğrudan etki ettiği anlaşılmaktadır.

Birgün gazetesinin haberinde yer verilen "hesap oyunuyla da başarısız oldular" şeklindeki ifade İmam Hatip Liselerini olumsuz bir çerçevede sunarken, geçmişte de "başka diğer oyunlar" içerisinde olunduğu algısı yaratılmak istenmiştir. Benzer şekilde “Örneklemde en dikkat çekici unsur (....) imam hatip lisesi gibi başarısız olan liselerin 
ise oranlarının düşmesi oldu." ifadeleri ile de İmam Hatiplere yönelik "başarısız lise" imajının çizildiği görülmektedir.

Cumhuriyet gazetesinde yer verilen haberde ise "AKP'nin “dindar nesil” umudu imam hatip liseleri PISA 2018'de çakıldı.” şeklindeki ifadeler ile İmam Hatipler bir yandan AK Parti ile özdeşleştirilirken diğer yandan ise "dindar nesil umudu” tanımlaması yapılmıştır. Haber metninin bütününde bir "başarısızlık" durumu inşa edilerek, “AKP'nin dindar nesil umudu”nun başarısızlıkla sonuçlandığg hatta “çakıldığı” mesajı verilmek istenmiştir. Söz konusu haberin başlığı da yine açıkça ideolojik bir yaklaşım şeklinde ortaya atılan "Geriden geliyorlar" ifadesidir. Söz konusu yayın organı sıklıkla "gericilik" atfettiği İmam Hatip Liselerine yönelik olumsuz yaklaşımı çalışma kapsamında incelenen haberde de açıkça görülmektedir.

Diğer gazetelerin haberlerinde haber başlığı ve spotunda İmam Hatip vurgusu yapılmadan “Liseliler" sözcügünün kullanıldığı saptanırken, Milli Gazete'nin ise İmam Hatip kimliğini ön plana çıkarılmıştır. Başarıyı destekler sayısal veriler aktarılarak, okurlara İmam Hatiplerin “iddialı” ve "başarılı” şeklinde sunduğu dikkat çekmektedir.

\section{Sonuç}

İmam Hatip okullarının bilimsel başarının medyada yer verilme biçiminin konu edinildiği bu çalışmada, Cumhuriyet, Birgün, Aydınlık, Milli Gazete, Sabah ve Star gazetelerinin 2019 yılı içerisinde söz konusu okulların bilimsel başarı durumlarına ilişkin yer verdikleri haberler eleştirel söylem analizi yöntemiyle değerlendirilmiştir.

Çalışma kapmasında incelenen haberlere bakıldığında Türk Milli Eğitim sistemi içerisinde kanun ve yönetmeliklerle sınırları belirlenen bir müfredata göre eğitim öğretim veren İmam Hatip okullarının ayrıştırıcı ve ötekileştirici bir yaklaşımla kamuoyuna yansıtıldıkları sonucuna varılmaktadır. Özellikle Cumhuriyet ve Birgün gazetelerinde İmam Hatiplere yönelik ideolojik bir bakışın egemen olduğu haberler dikkat çekicidir. Zira söz konusu gazetelerde İmam Hatip okullarının başarılı olduğu durumlar göz ardı edilerek, tarafsızlık ilkesinden uzak bir yaklaşımla İmam Hatipler için "başarısız" bir tablo çizildiği görülmektedir. Çalışma kapsamında ele alınan haberlerde İmam Hatiplere yönelik bu yaklaşım medyanın gündem belirleme ve ideolojik konumuna göre hareket ettiğinin önemli bir göstergesi olarak dikkat çekmektedir.

İmam Hatip okullarının, güncellenen müfredatlarıyla değişiklere hızla adaptasyon sağlarken, kamuoyunu bilgilendirmeye yönelik kültürel etkinlikler ve yürüttükleri sosyal sorumluluk projelerini gerek medya gerekse sivil toplum kuruluşlarıyla iş birliği içerisinde kamuoyu bilgisine sunmaları, bu okullara bakışın olumlu anlamda değişmesine katkı sağlayacağı düşünülmektedir. 


\section{Kaynakça}

Aydınlık, Robotik Yarışması 'nda 'İmkansızı'Başardılar, 17 Ağustos 2019.

Birgün, Hesap Oyunuyla da Başarısız Oldular, 5 Aralık 2019.

Cumhuriyet, Geriden Geliyorlar, 5 Aralık 2019.

Dijk, Teun A. van. 1988. New Analysis: Case Studies of International and National News in the Press. New Jersey: Lawrence Erlbaum Associates Publishers.

Doruk, Özlem. 2013. «Disiplin Toplumu ve Haber Söylemi: Gökkuşağı Derneği’nce Yapılması Planlanan Yürüyüşün Engellemesine İlişkin Haberlerin Çözümlenmesi .» Gümüşhane Üniversitesi İletişim Fakültesi Elektronik Dergisi 106-132.

Ergül, Hakan. 2005. Televizyonda Haberin Magazinleşmesi. İstanbul: İletişim Yayınları.

Güneş, Ahmet. 2014. «Gündem Belirleme Teorisi Bağlamında 30 Mart 2014 Yerel Seçimlerinin Basında Sunumu: AKP ve CHP Örneği.» tojdac.org Web Sitesi. Nisan. Erişildi: Aralık 19, 2014. http://www.tojdac.org/tojdac/VOLUME4-ISSUE2_files/tojdac_v04i201.pdf.

Girgin, Atilla. 2002. Yazılı Basında Haber. İstanbul: İnkılap Kitabevi.

İnal, Ayşe M. 1996. Haberi Okumak. İstanbul: Temuçin Yayınları.

Laclau, Ernesto. 2009. «Evrenselliği İnşa Etmek.» Olumsallık Hegemonya Evrensellik içinde, yazan Ernesto Laclau, Slavoj Zizek ve Judith Butler, 311-340. İstanbul: Hil Yayınları.

Milli Gazete, LGS'ye Imam Hatip Damgası, 29 Haziran 2019.

Ozankaya, Özer. 1980. Toplumbilim Terimleri Sözlüğü. Ankara: TDK.

Önder İmam Hatipliler Derneği. 2019. «Gazetelerde İmam Hatiplere Bakış 2019.» Araştırma, İstanbul, 18.

Özer, Ömer. 2001. Haber Söylem İdeoloji: Eleştirel Haber Çözümlemeleri. Konya: Literatürk Yayınevi.

Sabah, Erkeklerde Olan Beyin Bizde de Var, 26 Ocak 2019.

Said, Edward. 2006. Medyada İslam. İstanbul: Metis Yayınları.

Star, Liseliler Teknofestte Başarı Hikayesi Yazdı, 28 Eylül 2019.

Terkan, Banu. 2005. Gündem Belirleme. Konya: Tablet Kitabevi.

Yaylagül, Levent. 2006. Kitle İletişim Kuramları Egemen ve Eleştirel Yaklaşımlar. Ankara: Dipnot Yayınevi. 